Article

\title{
Perceptions, Risk Attitude and Organic Fertilizer Investment: Evidence from Rice and Banana Farmers in Guangxi, China
}

\author{
Xinjian Chen ${ }^{1, * \mathbb{D}}$, Di Zeng ${ }^{2}$, Ying $\mathrm{Xu}^{2}$ and Xiaojun Fan ${ }^{1}$ \\ 1 Business School, Guangxi University, Nanning 530004, China; xdfxj@126.com \\ 2 The Centre for Global Food and Resources, The University of Adelaide, Adelaide 5005, Australia; \\ di.zeng@adelaide.edu.au (D.Z.); ying.xu03@adelaide.edu.au (Y.X.) \\ * Correspondence: xjchen@gxu.edu.cn
}

Received: 5 September 2018; Accepted: 11 October 2018; Published: 16 October 2018

check for updates

\begin{abstract}
Overuse of chemical fertilizer has led to severe land degradation and environmental pollution in China. Switching to organic fertilizer may improve soil quality and reduce pollution, which is meaningful to the sustainable development of Chinese agriculture. This study examines how farmers' perceptions and risk preference affect their organic fertilizer investment using a representative rural household survey from Guangxi, a major agricultural region in China. Tobit and double-hurdle models are used to empirically test their impacts on organic fertilizer adoption and investment. An ordinary least squares model is used to regress chemical fertilizer use on the same set of explanatory variables to compare and contrast farmers' different fertilizer investment behaviors. It is found that both organic fertilizer perceptions and risk attitude significantly affect organic fertilizer investment. Perceived yield-increasing and quality-improving effects encourage organic fertilizer investment, while perceived cost increases discourage it. Moreover, risk-averse farmers are more likely to invest in organic fertilizers. Most of the perceptions affecting organic fertilizer investment have an opposite impact on chemical fertilizer investment, which suggests substitutability between organic and chemical fertilizer. Interventions that aim to improve farmers' perceptions of organic fertilizer and illustrate its risk-reduction effect could be effective in promoting organic fertilizer use, which can help achieve China's sustainable development of agriculture.
\end{abstract}

Keywords: organic fertilizer; perception; risk preference; rice; banana; China

\section{Introduction}

Fertilizers play a very important role in increasing the crop output and ensuring food security in many countries. However, the overuse of chemical fertilizer has led to severe environmental issues such as land degradation, non-point source pollution, and greenhouse gas emissions [1-5]. In China, the world's largest consumer of chemical fertilizer, overuse of chemical fertilizers is more serious [6]. In 2015, China consumed 60 million tons of chemical fertilizer [7], accounting for over 30\% of world chemical fertilizer consumption on only $9 \%$ of global cropland [8]. Reduction of chemical fertilizer use is needed to mitigate these negative effects, which can be done while still meeting China's food demand [9]. Consequently, the Chinese government has recently exerted increasing efforts to reduce chemical fertilizer overuse and aim to reach zero growth in chemical fertilizer and pesticides use by 2020, which specifies incentive subsidies and tax exemption to organic fertilizers as well as formula fertilization with soil testing $[10,11]$. It is widely recognized that organic fertilizer can significantly improve soil quality and nutrition, farm productivity, and avoid adverse environmental and health impacts from agricultural chemical use and thus help achieve sustainable agricultural 
development $[2,12-17]$. However, the adoption rate of organic fertilizer is still low compared to the increasing usage of chemical fertilizer because many farmers fear the loss of crop output and the odor of organic fertilizer [18,19]. Understanding the determinants of organic fertilizer adoption, especially the factors driving farmers' decisions about the adoption of organic fertilizers, is relevant for informing policy-making towards the negative environmental impacts and may help China achieve its sustainable agriculture development goals, such as the zero growth of chemical fertilizers and pesticides, and recycling utilization of animal and plant waste [20].

Existing studies suggest that fertilizer investment depends on numerous factors, including individual characteristics of the farm or farmer [2,15], off-farm employment [21], knowledge training [18,22], as well as socioeconomic factors such as fertilizer supply chain [23] and the policy environment [24]. Certain factors are found to have inconsistent impacts. For instance, some studies argue that organic fertilizer is a long-term investment option for farmers, and land tenure security is an important factor affecting its use [25-27], while others only find the impact of land tenure on investment in soil conservation measures to be weak [28,29]. Empirical evidence from Asian developing countries also suggests that off-farm work and agricultural cooperatives may be important in promoting investments in organic soil amendments [13,21]. Clearly, farmers' fertilizer investment decisions are jointly affected by a variety of factors, yet most studies focus on observable characteristics, leaving possible psychological determinants much less understood.

Among the possible psychological factors, perceptions and risk attitude are perhaps the most important ones. Existing studies suggest that farmer's perceptions towards organic fertilizer tend to influence their investment on soil-improving practices [22,30,31]. In Denmark, Case et al. [30] show that soil structure improvement is the most important reason to use organic fertilizer, while unpleasant odor, uncertainty in nutrient content, and difficulty in planning and use are the major barriers. Using data from multiple European countries, Hou et al. [32] found that perceived high cost and long payback period are the main barriers of investment in organic fertilizer. In addition, farmers in developing countries are generally found to be risk averse against production and climate volatilities [33-35], which can influence their investment in inputs and agricultural technologies [36-42]. For instance, production uncertainty may lead to the overuse of fertilizers $[43,44]$. As soil improvement may potentially safeguard crop growth against production risks [12], it may incentivize risk-averse farmers to switch towards organic fertilizer.

Despite these appealing logics, few studies have specifically analyzed whether and how the above-mentioned factors affect Chinese farmers' organic fertilizer investment. The possible linkages between perceptions, risk preference, and organic fertilizer adoption/investment need to be better understood, because China consumes one third of world's chemical fertilizer [8], and farmers' fertilizer use patterns would have significant implications for global environmental change. Potential policy practices, such as official guidelines that aim to promote organic fertilizer in China, may also inform decision makings in other countries through demonstration effects. The need for such knowledge motivates the current study.

We use a comprehensive rural household survey in Guangxi Autonomous Region (province equivalent), a major agricultural region in southern China, to empirically test the possible linkages between farmer's perceptions, risk preference, and fertilizer investment. Rice and banana farmers are included in the study. As the most important crops in Guangxi province, rice and banana crops occupy about two million hectares of farmland and serve as the sources of the main household income to more than 20 million people [45]. Rice and banana crops are also selected because staple and horticultural farmers may exhibit varying fertilizer investment behaviors, and parallel analysis of these two crops can provide a better picture of organic fertilizer investment. Moreover, plenty of commercial organic fertilizers (e.g., organic fertilizers made from animal manure and cane sugar refinery waste) are supplied in the rural input market of Guangxi. Therefore, Guangxi provides an ideal context for our study. 
The rest of the article is organized as follows. Section 2 describes the survey data and analytical methods. Section 3 presents the empirical results and their robustness. Section 4 provides discussion with policy implications, Section 5 concludes our findings.

\section{Methods and Data}

\subsection{Methods}

To investigate organic fertilizer adoption, especially the possible roles of perceptions and risk attitude, a Tobit model is estimated. The Tobit model is appropriate in our case as: (1) not all farmers adopt organic fertilizer; and (2) the usages (measured by organic fertilizer expenditure) vary among adopters. The Tobit model is specified as follows:

$$
\begin{gathered}
Y_{i}^{*}=\alpha_{1} P R_{i}+\alpha_{2} A R_{i}+\alpha_{3} X_{i}+\epsilon_{i} \\
Y_{i}=\left\{\begin{array}{cl}
Y_{i}^{*}, & \text { if } Y_{i}^{*}>0 \\
0, & \text { if } Y_{i}^{*} \leq 0
\end{array}\right.
\end{gathered}
$$

In Equation (1), the latent variable $Y_{i}^{*}$ is a stochastic variable that measures the investment of farmer $i$ on organic fertilizer or chemical fertilizer in their farm, which takes the value of household's expenditure on organic fertilizers per hectare or zero otherwise. $P R_{i}$ represents farmer $i$ 's perceptions toward organic fertilizer, which are described in Tables 1 and 2. $A R_{i}$ is farmer $i$ 's absolute risk aversion coefficient, the computation method of which is explained below. $X_{i}$ is a set of demographic and socioeconomic characteristics that possibly affect farmer $i^{\prime}$ s organic fertilizer investment. $\alpha_{1}, \alpha_{2}$ and $\alpha_{3}$ are vectors of parameters to be estimated, and $\epsilon_{i}$ is the normally distributed random disturbance.

To compare and contrast organic fertilizer investment, an ordinary least squares (OLS) estimation was performed for chemical fertilizer investment. Unlike the organic fertilizer case where only some of the farmers adopt/invest in it, OLS regression is appropriate for chemical fertilizer use since all farmers adopt it, thereby having positive amounts of monetary investment. The linear regression model takes the form of Equation (1) with the latent outcome on the left-hand side replaced by the observed chemical fertilizer investment.

As organic fertilizer investment is our primary interest, a double-hurdle model proposed by Cragg [46] was further estimated to help check the robustness of our Tobit model estimates and statistical inferences. The adoption equation and the investment equation in the double-hurdle model are respectively specified as:

$$
\begin{aligned}
& Z_{i}^{*}=\beta_{1} P R_{i}+\beta_{2} A R_{i}+\beta_{3} X_{i}+u_{i} \\
& Y_{i}^{*}=\gamma_{1} P R_{i}+\gamma_{2} A R_{i}+\gamma_{3} X_{i}+v_{i}
\end{aligned}
$$

where $Z_{i}^{*}$ is a latent organic fertilizer adoption indicator and $Y_{i}^{*}$ is latent investment. $\beta_{1}, \beta_{2}, \beta_{3}, \gamma_{1}$, $\gamma_{2}$ and $\gamma_{3}$ are vectors of parameters to be estimated, and $u_{i}$ and $v_{i}$ are independently and normally distributed with a zero mean and unitary variance. The observed investment $Y_{i}$ relates to the latent investment $Y_{i}^{*}$ such that:

$$
Y_{i}=\left\{\begin{array}{cl}
Y_{i}^{*}, & \text { if } Z_{i}^{*}>0 \\
0, & \text { if } Z_{i}^{*} \leq 0
\end{array}\right.
$$

The double-hurdle model is different from the Tobit model as it allows separate stochastic processes for the participation and consumption decisions. Therefore, it serves as an ideal robustness check exercise.

In empirical analysis, a common approach of a lottery-choice experiment is employed to elicit the farmer's risk preference. The choice experiment uses a "multiple price list" (MPL) design where farmers are presented with several lottery choices all at once, following Binswanger and Sillers [47], Holt and Laury [34], and Yusuf [35]. This experiment method is easy to explain to farmers and the data obtained from this approach is easily interpreted [48]. In the risk preference experiment, a farmer 
makes a series of ten choices between two lotteries, A and B, reported in Table A1 in the Appendix A. Option A is the "safe" choice whose payoff is less variable than the potential payoff in the "risky" option B. For each decision, a farmer has to choose either option A or option B and should cross over to option $B$ when the probability of the high payoff increases enough. Although ten decisions are made, only one is randomly selected as binding. The farmer's choices are then used to determine risk preference using a utility function. The details are provided in the Appendix A.

\subsection{Survey and Data Description}

This study was facilitated using a rural household survey conducted in Guangxi, China from August 2016 to June 2017. A multi-stage stratified sampling strategy was used in data collection. In the first stage, primary sample areas were selected according to the ranked contribution of rice/banana to local agricultural economy based on historical production data. Seven prefectural-level cities were selected, representing $50 \%$ of the total of 14 prefectural-level cities in Guangxi as the primary sample units. In China, prefectural-level city is an administrative division, ranked below a province and above a county in China's administrative structure. It is not often a "city" as it usually contains multiple rural counties and equivalent subdivisions. Therefore, farmers are well represented in prefectural-level cities. According to the first stage sampling, the survey covers seven prefectural-level cities-Nanning, Baise, Guigang, Yulin, Qinzhou, Guilin, and Liuzhou-which jointly contribute about $60 \%$ of rice and $80 \%$ of banana production of the province. Figure 1 shows the locations of these cities. In the second stage, 12 rice-producing counties and 10 banana-producing counties were selected, which represent $50 \%$ of the total of 24 major rice-producing counties and 20 major banana-producing counties in these prefectural-level cities according to the aggregate rice and banana cultivation areas in the past four years (2013-2016). In the third stage, three towns in the top ten towns were randomly selected in terms of rice/banana production in each county. Finally, fifteen rice farmers and ten banana farmers were randomly chosen from each town. As the focus of the survey is fertilizer investment, the surveyed households selected in these samples have met two conditions: (1) rice/banana is grown for commercial markets rather than mere self-sufficiency; and (2) rice/banana cultivation is the major source of household income. According to the survey, a total of 480 rice households and 290 banana households were sampled in 36 rice-producing and 30 banana-producing towns, among whom 365 rice farmers and 240 banana farmers were interviewed and have all information appropriately recorded (with an average effective response rate of $78.6 \%$ ).

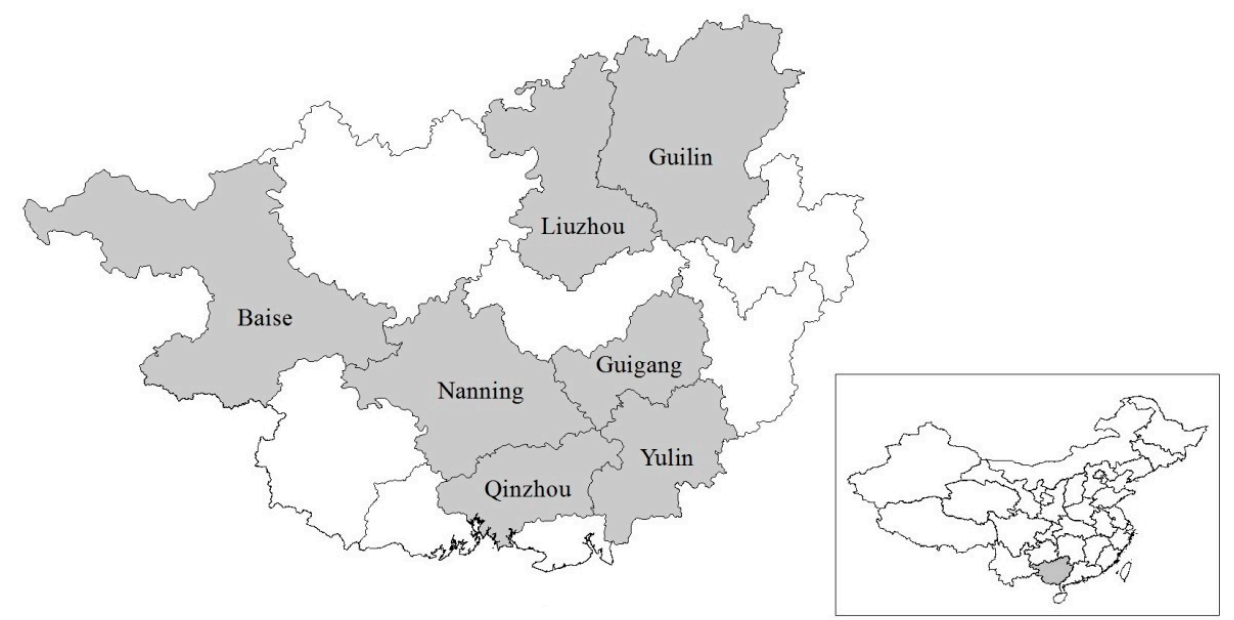

Figure 1. The locations of study sites in Guangxi Autonomous Region, China. Source: Authors' own mapping.

The survey consisted of regular questions and a choice experiment eliciting the risk attitude of respondents. Household data include: (1) farmers' demographic characteristics such as gender, 
age and education; (2) farmers' household characteristics, such as number of household members and off-farm work; (3) farm characteristics such as farm size, farm type, and input and output details including organic and chemical fertilizer investments; (4) farmers' multiple perceptions toward organic fertilizer; and (5) farmers' risk preference estimated using a lottery-choice experiment with actual production data.

Table 1 presents descriptive statistics of the outcome variables and covariates from the survey. A total of $41 \%$ of the rice farmers and $61 \%$ of the banana farmers used organic fertilizer, whereas all households applied chemical fertilizer in their farms. The average organic fertilizer investment was much larger among banana farmers, which could possibly be explained by the different agronomic features of these plants. Unlike rice, which is a staple crop, banana is a horticultural/cash crop, where farmers can be much more profit-driven and thus keener regarding organic fertilizer investment. Among the covariates, perceptions of organic fertilizers and risk attitude are our primary interest. It was seen that banana farmers generally agreed more on the advantages of organic fertilizers and agreed less on the disadvantages than rice farmers, with such discrepancies possibly coming from the varying agronomic features of the two crops. More than $82 \%$ of rice farmers and $68 \%$ of banana farmers were risk averse from the risk preference experiment, and the average risk aversion coefficient of rice farmers was 0.11 (risk averse to very risk averse class) and 0.06 (slightly risk averse class) of banana farmers. Thus, rice farmers were more risk averse. Most of the household and farm characteristics appeared to be similar between rice and banana farmers except that banana farms were noticeably larger (5.89 ha) than rice farms (2.13 ha).

Table 1. Descriptions of variables used to assess organic fertilizer investment of farmers.

\begin{tabular}{|c|c|c|c|}
\hline \multirow{2}{*}{ Variables } & \multirow{2}{*}{ Definition } & \multicolumn{2}{|c|}{ Mean (SD) } \\
\hline & & Rice & Banana \\
\hline \multicolumn{4}{|c|}{ Investment variables } \\
\hline Organic fert. adoption & 1 if farmer use organic fertilizer, 0 otherwise & $0.41(0.49)$ & $0.61(0.48)$ \\
\hline Organic fert. investment & Expenditure on organic fertilizer (USD/ha) ${ }^{1}$ & $64.02(80.94)$ & $1103(978.3)$ \\
\hline Chem. fert. adoption & 1 if farmer use chemical fertilizer, 0 otherwise & $1.00(0.00)$ & $1.00(0.00)$ \\
\hline Chem. fert. investment & Expenditure on chemical fertilizer (USD/ha) & $283.1(59.91)$ & $2059(418.9)$ \\
\hline \multicolumn{4}{|c|}{ Farmers' perceptions toward organic fertilizer (5-point scale: $1=$ strongly disagree; $5=$ strongly agree) } \\
\hline Environ. friendliness & Organic fertilizer is friendly to environment & $3.45(1.07)$ & $3.54(0.86)$ \\
\hline Soil-improving & Using organic fertilizer can improve soil & $3.49(0.97)$ & $3.65(0.94)$ \\
\hline Yield-increasing & Using organic fertilizer can increase yield & $2.59(1.12)$ & $3.31(1.13)$ \\
\hline Quality-improving & Using organic fertilizer can increase quality & $2.67(0.89)$ & $3.55(1.05)$ \\
\hline Cost-increasing & The use cost of organic fertilizer is high & $3.76(0.91)$ & $3.53(0.87)$ \\
\hline Slow effect & The effect of organic fertilization is slow & $3.92(1.10)$ & $3.57(1.01)$ \\
\hline \multicolumn{4}{|c|}{ Farmers' risk preference } \\
\hline Risk aversion & Risk aversion coefficient estimated by experiment & $0.11(0.10)$ & $0.06(0.10)$ \\
\hline \multicolumn{4}{|c|}{ Household-level and farm-level characteristics } \\
\hline Age & Age of household head (years) & $48.78(8.83)$ & $48.10(9.29)$ \\
\hline Gender & Gender of household head $(1=$ male; $0=$ female $)$ & $0.91(0.28)$ & $0.86(0.35)$ \\
\hline Education & Education of household head (years) & $7.77(2.59)$ & $8.05(2.39)$ \\
\hline Household size & Number of household members & $4.39(1.08)$ & $4.57(1.24)$ \\
\hline Farm size & Total farm size of rice/banana (ha) & $2.13(3.28)$ & $5.89(8.85)$ \\
\hline Asset & $\begin{array}{l}1 \text { if rice farmer owns rotary cultivator or banana farmer owns } \\
\text { four-wheel steering agricultural vehicles, } 0 \text { otherwise }\end{array}$ & $0.37(0.48)$ & $0.48(0.50)$ \\
\hline Soil fertility & $\begin{array}{l}\text { Farmers' self-report about farm soil fertility ( } 5 \text {-point scale: } 1 \text { = worst; } \\
5=\text { best) }\end{array}$ & $3.29(1.11)$ & $2.66(1.00)$ \\
\hline Tenure security & $\begin{array}{l}1 \text { if farmer perceives that land user rights will not change within next } \\
\text { five years; } 0 \text { otherwise }\end{array}$ & $0.69(0.45)$ & $0.62(0.48)$ \\
\hline Membership & 1 if farmer is a cooperative member, 0 otherwise & $0.32(0.46)$ & $0.38(0.48)$ \\
\hline Training & $\begin{array}{l}1 \text { if farmer had received training in fertilization techniques, } 0 \\
\text { otherwise }\end{array}$ & $0.38(0.48)$ & $0.40(0.49)$ \\
\hline Distance to farm & $\begin{array}{l}\text { Farmers' self-reported distance between farm and home }(1=\text { close; } \\
2 \text { = fair; } 3=\text { far })\end{array}$ & $2.03(0.82)$ & $2.16(0.80)$ \\
\hline
\end{tabular}

Notes: ${ }^{1} 1$ USD $=6.64$ Chinese Yuan in 2016. Standard deviations are reported in parentheses. Source: Authors' survey. 
Table 2 further differentiates adopters and non-adopters of organic fertilizer among rice and banana farmers in reporting descriptive statistics. Pairwise $t$-tests are performed to check whether adopters and non-adopters significantly differ in observed characteristics. It is seen that, organic fertilizer adopters used significantly lower amount of chemical fertilizers, suggesting the possible substitution between these two. Compared to non-adopters, adopters were more likely to perceive the environmental friendliness of organic fertilizer, as well as its yield-increasing and quality-improving effects, and tended not to perceive high costs as a barrier of adoption. Moreover, adopters were more risk averse, observing higher average risk aversion coefficients for both crops. For both crops, organic fertilizer adopters were generally better educated, richer, more tenure secure, more likely to be cooperative members, and more likely to have had experience in organic-fertilizer-related training. However, for rice farmers, organic fertilizer adopters usually had smaller farm size, while for banana farmers, they often had larger size. Finally, non-adopters usually possessed more optimistic beliefs about their soil fertility than adopters. These statistically significant discrepancies directly point to the need for controlling these confounding factors in the following analysis, to correctly separate out and thus successfully identify the hypothesized impacts of perceptions and risk attitude, which is of our interest.

Table 2. Descriptive statistics of organic fertilizer adopter and non-adopter samples.

\begin{tabular}{ccccc}
\hline \multirow{2}{*}{ Variables } & \multicolumn{3}{c}{ Rice } & \multicolumn{2}{c}{ Banana } \\
\cline { 2 - 4 } & Adopter (n= 151) & Non-Adopter $(\mathbf{n}=\mathbf{2 1 4})$ & Adopter (n= 146) & Non-Adopter (n = 94) \\
\hline Organic fert. investment & $154.7(42.05)$ & $0.00^{* *}(0.00)$ & $1813(530.1)$ & $0.00^{* *}(0.00)$ \\
Chem. fert. investment & $218.4(25.14)$ & $328.7^{* *}(25.05)$ & $1878(358.9)$ & $2340^{* *}(344.9)$ \\
Environ. friendliness & $3.64(1.00)$ & $3.33^{* *}(1.09)$ & $3.69(0.89)$ & $3.28^{* *}(0.76)$ \\
Soil-improving & $3.59(0.98)$ & $3.41(0.96)$ & $3.92(0.73)$ & $3.21^{* *}(1.06)$ \\
Yield-increasing & $3.44(0.99)$ & $1.99^{* *}(0.78)$ & $3.82(0.98)$ & $2.52^{* *}(0.86)$ \\
Quality-improving & $3.25(0.72)$ & $2.25^{* *}(0.76)$ & $4.15(0.73)$ & $2.62^{* *}(0.75)$ \\
Cost-increasing & $3.24(0.81)$ & $4.12^{* *}(0.78)$ & $3.08(0.66)$ & $4.20^{* *}(0.73)$ \\
Slow effect & $3.96(1.06)$ & $3.89(1.14)$ & $3.61(0.99)$ & $3.50(1.04)$ \\
Risk aversion & $0.17(0.12)$ & $0.06^{* *}(0.07)$ & $0.11(0.08)$ & $-0.01^{* *}(0.07)$ \\
Age & $49.22(8.91)$ & $48.47(8.78)$ & $46.81(9.47)$ & $50.11^{* *}(8.67)$ \\
Gender & $0.88(0.32)$ & $0.93(0.25)$ & $0.84(0.37)$ & $0.89(0.31)$ \\
Education & $8.27(2.56)$ & $7.42^{* *}(2.55)$ & $8.96(2.33)$ & $6.63^{* *}(1.69)$ \\
Household size & $4.43(1.14)$ & $4.37(1.04)$ & $4.63(1.32)$ & $4.49(1.10)$ \\
Farm size & $1.64(3.92)$ & $2.48^{* *}(2.69)$ & $7.45(9.86)$ & $3.49^{* *}(6.35)$ \\
Asset & $0.51(0.50)$ & $0.27^{* *}(0.45)$ & $0.61(0.49)$ & $0.29^{* *}(0.45)$ \\
Soil fertility & $2.53(0.89)$ & $3.82^{* *}(0.92)$ & $2.29(0.89)$ & $3.23^{* *}(0.88)$ \\
Tenure security & $0.91(0.28)$ & $0.55^{* *}(0.49)$ & $0.85(0.35)$ & $0.27^{* *}(0.44)$ \\
Membership & $0.53(0.50)$ & $0.17^{* *}(0.38)$ & $0.55(0.49)$ & $0.12^{* *}(0.32)$ \\
Training & $0.60(0.49)$ & $0.22^{* *}(0.42)$ & $0.53(0.50)$ & $0.19^{* *}(0.39)$ \\
Distance to farm & $2.14(0.81)$ & $1.95^{*}(0.82)$ & $2.13(0.83)$ & $2.21(0.76)$ \\
\hline
\end{tabular}

Notes: Standard deviations are reported in parentheses. ${ }^{*}$ and ${ }^{* *}$ indicate the variable mean differs from that of organic fertilizer non-adopters at $5 \%$ and $1 \%$ levels, respectively. Source: Authors' survey.

\section{Results}

Table 3 represents the regression results of organic and chemical fertilizer investment, respectively. Rice and banana farmers were analyzed in a parallel manner to compare the findings. All models were appropriately identified. The linear regression model predicting chemical fertilizer investment also provided an opportunity to test for possible multicollinearity. A variance inflation factors (VIF) test was performed, while all VIF values were less than 3 . This concern was therefore minimized and our specification could be considered appropriate. 
Table 3. Regression results of organic and chemical fertilizer investment.

\begin{tabular}{ccccc}
\hline \multirow{2}{*}{ Variables } & \multicolumn{2}{c}{ Rice $(\mathbf{n}=\mathbf{3 6 5})$} & \multicolumn{2}{c}{ Banana $(\mathbf{n}=\mathbf{2 4 0 )}$} \\
\cline { 2 - 5 } & $\begin{array}{c}\text { Organic } \\
\text { (Tobit Model) }\end{array}$ & $\begin{array}{c}\text { Chemical } \\
\text { (OLS Model) }\end{array}$ & $\begin{array}{c}\text { Organic } \\
\text { (Tobit Model) }\end{array}$ & $\begin{array}{c}\text { Chemical } \\
\text { (OLS Model) }\end{array}$ \\
\hline Environ. friendliness & $3.657(3.867)$ & $0.197(1.643)$ & $-3.353(40.22)$ & $-4.633(22.59)$ \\
Soil-improving & $4.265(4.216)$ & $0.192(1.847)$ & $114.6^{* * *}(44.20)$ & $-58.60^{* * *}(21.52)$ \\
Yield-increasing & $30.54^{* * *}(5.337)$ & $-15.55^{* * *}(2.171)$ & $200.9^{* * *}(40.34)$ & $-57.30^{* * *}(21.39)$ \\
Quality-improving & $39.43^{* * *}(5.417)$ & $-26.14^{* * *}(2.345)$ & $368.3^{* * *}(49.72)$ & $-101.4^{* * *}(25.50)$ \\
Cost-increasing & $-13.61^{* *}(5.679)$ & $8.119^{* * *}(2.356)$ & $-240.8^{* * *}(50.09)$ & $59.98^{* *}(26.75)$ \\
Slow effect & $3.266(3.612)$ & $-1.372(1.564)$ & $65.28^{* *}(34.68)$ & $-31.58^{*}(18.64)$ \\
Risk aversion & $109.9^{* *}(45.90)$ & $-73.14^{* * *}(22.00)$ & $1625^{* * *}(449.5)$ & $1228^{* * *}(253.1)$ \\
Age & $0.277(0.472)$ & $-0.147(0.202)$ & $2.768(3.910)$ & $-10.43^{* * *}(2.232)$ \\
Gender & $-11.41(13.26)$ & $6.293(6.175)$ & $-119.2(95.23)$ & $31.24(54.23)$ \\
Education & $7.821^{* * *}(1.684)$ & $-2.590^{* * *}(0.684)$ & $45.96^{* *}(18.35)$ & $-47.11^{* * *}(10.33)$ \\
Household size & $-11.91^{* * *}(3.958)$ & $1.864(1.644)$ & $-6.056(27.34)$ & $-6.451(15.34)$ \\
Farm size & $2.891^{* *}(1.214)$ & $-1.743^{* * *}(0.613)$ & $0.953(4.083)$ & $0.682(2.442)$ \\
Asset & $5.316(8.791)$ & $-4.915(3.917)$ & $78.59(78.16)$ & $12.91(43.04)$ \\
Soil fertility & $-35.29^{* * *}(5.023)$ & $-1.534(2.121)$ & $-133.9 * *(52.73)$ & $13.98(27.22)$ \\
Tenure security & $33.34^{* * *}(11.29)$ & $-13.51^{* * *}(4.123)$ & $506.8^{* * *}(85.30)$ & $-89.79^{* *}(45.12)$ \\
Membership & $9.330(9.091)$ & $-7.587^{* *}(4.205)$ & $132.9(88.66)$ & $-128.2^{* *}(51.60)$ \\
Training & $24.11^{* * *}(8.709)$ & $-12.78^{* * *}(3.952)$ & $127.2^{*}(75.63)$ & $-79.39^{*}(42.74)$ \\
Distance to farm & $2.045(4.909)$ & $-1.444(2.142)$ & $-23.17(42.42)$ & $-19.21(23.64)$ \\
LR $\chi^{2}$ & $449.9^{* * *}(0.00)$ & & $431.3^{* * *}(0.00)$ & $16.68^{* * *}(0.00)$ \\
F value & & $49.74^{* * *}(0.00)$ & & \\
\hline
\end{tabular}

Notes: The outcome variable is organic or chemical fertilizer investment in the respective case. Standard errors are reported in parentheses. ${ }^{*}, * *$, and ${ }^{* * *}$ indicate statistical significance at $10 \%, 5 \%$, and $1 \%$ levels, respectively. Source: Authors' survey.

\subsection{Determinants of Rice Farmers' Organic Fertilizer Investment}

The perceptions of organic fertilizer play important roles in rice farmers' investment decisions. Specifically, perceived yield-increasing and quality-improving effects significantly encouraged organic fertilizer investment, while perceived cost-increasing discouraged it. The results regarding the influence of economic factors and adoption cost are consistent with Hou et al. [32] in Europe, who found that the major barriers to manure treatment technology adoption were related to economic factors and high processing cost. Comparatively, the result is not consistent with Wang et al. [19] who argued that expected revenue gain due to increase in yield does not significantly affect apple farmer's choice of organic fertilizer in China. The results also show that perceived soil improving effect was not found to affect organic fertilizer investment, though adopters generally perceived their soil quality to be poorer than non-adopters (see Table 2). Moreover, neither perceived slow effect nor environmental friendliness was associated with organic fertilizer investment. Intuitively, local environmental quality, mostly a public good, was not within the farmers' consideration in fertilizer investment decision, the latter of which were largely associated with the profit-maximizing arguments (yield-increasing, quality-improving, and cost-increasing). This is in line with studies suggesting farmers' awareness of water erosion and soil fertility decline is not significantly associated with land management investments [22,31].

The impacts of organic fertilizer perceptions on chemical fertilizer investment are also reported in Table 3. All perceptions have opposite impacts. That is, perceived yield-increasing and quality-improving effects of organic fertilizer discourage chemical fertilizer investment, while a perceived cost increase of the former encourages it. These patterns jointly imply the substitutability between the two fertilizer types. This echoes with Zhao et al. [49] who suggest organic fertilizer use may reduce chemical fertilizer use in China. As expected, perceived environmental friendliness, soil improving effect, or slow effect of organic fertilizer were not affecting the amount of chemical fertilizer investment.

Risk attitude plays key role in fertilizer selection. Risk-averse farmers, as captured by the coefficient of absolute risk aversion, were more likely to invest in organic fertilizer. These farmers also tended to invest less in chemical fertilizer. Therefore, risk aversion stimulates the switch towards organic fertilizer. These results are consistent with Isik and Khanna [44] and Ramaswami [41]. 
Intuitively, organic fertilizer can alleviate production risk through both conservation and yield benefits $[12,50]$, and can be an effective risk management strategy.

Meaningful patterns were also observed among other covariates. Higher organic fertilizer investment was associated with better education, larger farm size, more secure land tenure, and previous organic fertilizer related training; these covariates all had opposite impacts on farmers' chemical fertilizer investment. Generally, the results are in line with Huang et al. [18], Wu et al. [2], Rakhshanda and Awudu [21], and Xu et al. [15]. In addition, better soil fertility discouraged organic fertilizer use, which confirmed the pattern observed in Table 2 and implied farmers' general awareness of the conservation benefits of organic fertilizer. On the contrary, Yusuf et al. [22] found that farmer perception of soil erosion was not associated with investments in soil fertility control measures. The impact of farm size was relatively small. It is speculated that larger rice farmers may emphasize more on cost management. If there is little yield gain with organic fertilizer (as captured by the low broad agreement on yield-increasing effect, see Table 1), farmers may not be well incentivized.

\subsection{Determinants of Banana Farmers' Organic Fertilizer Investment}

Results from banana farmers exhibit similar yet slightly different patterns as compared to those from rice farmers. Like the rice model, perceived yield-increasing and quality-improving effects encouraged organic fertilizer investment, and a perceived cost increase discourages it. Different from the rice model, a perceived soil-improving effect significantly encouraged organic fertilizer investment. This result is consistent with Case et al. [30] who found soil structure improvement was the most important reason to use organic fertilizer among Danish farmers. Compared to rice farmers, banana farmers generally perceived their soil fertility to be poorer (Table 1), and thus tended to apply organic fertilizer for conservation benefits. Moreover, the perceived slow effect of organic fertilizer was now found to be associated with increased investment among banana farmers, though the coefficient estimate was only marginally significant (at the $10 \%$ level). This is interesting because the slow effect, which was probably a disadvantage to rice cultivation, could indeed be an advantage for banana crops, which have a longer growth season (10-15 months), where the slow release of nutrients could potentially be desirable. This is quite different from existing research suggesting that the slow effect is a barrier to organic fertilizer use [32]. Similar to the rice model, environmental friendliness was not a driver of organic fertilizer investment among banana farmers. For chemical fertilizer, these perceptions all had opposite impacts on the investment, again suggesting the substitutability between these two. Moreover, these perceptions had much larger impacts among banana farmers compared to rice farmers, which agrees with the fact that organic fertilizer investment was much larger among banana farmers.

Risk aversion was positively associated with both organic and chemical fertilizer investments, which differed from rice where risk-averse farmers used less chemical fertilizer. It is known that rice needs more nitrogen, while banana needs more potassium [51]. However, potassium mainly comes from chemical fertilizer, and thus banana farmers have to use some chemical fertilizer. The impact magnitude of risk aversion was much larger for banana farmers than it is for rice farmers, which was intuitive as bananas require higher levels of investment and farmers may be more cautious in investment decision making.

Other factors encouraging organic fertilizer investment among banana farmers included education, tenure security, training, and soil fertility. All these significant determinants also had an opposite effect on chemical fertilizer investment. In addition, cooperative members tended to use less chemical fertilizer and had possibly utilized alternative technologies or input services from the cooperative. This is again consistent with those found by Ma et al. [13] and Wang et al. [19].

\subsection{Robustness Check with Double-Hurdle Model}

The impacts of perceptions and risk attitude on organic fertilizer investment were also evaluated using double-hurdle model. Results of both the decision model and investment model are in Table 4 . 
Table 4. Robustness check of organic fertilizer investment using double-hurdle model.

\begin{tabular}{|c|c|c|c|c|}
\hline \multirow{2}{*}{ Variables } & \multicolumn{2}{|c|}{ Rice $(n=365)$} & \multicolumn{2}{|c|}{ Banana $(n=240)$} \\
\hline & Decision Model & Investment Model & Decision Model & Investment Model \\
\hline Environ. friendliness & $-0.011(0.116)$ & $1.339(1.161)$ & $0.298(0.256)$ & $3.840(18.18)$ \\
\hline Soil-improving & $0.102(0.134)$ & $1.181(1.246)$ & $0.139(0.209)$ & $50.56^{* *}(22.84)$ \\
\hline Yield-increasing & $0.812^{* * *}(0.193)$ & $12.51^{* * *}(1.741)$ & $0.542 * *(0.224)$ & $75.13^{* * *}(20.17)$ \\
\hline Quality-improving & $1.205^{* * *}(0.205)$ & $0.188(1.743)$ & $1.200^{* * *}(0.322)$ & $81.15^{* * *}(25.65)$ \\
\hline Cost-increasing & $-0.489^{* * *}(0.190)$ & $-12.67 * * *(1.887)$ & $-0.757^{* * *}(0.285)$ & $-32.75(24.94)$ \\
\hline Slow effect & $0.122(0.113)$ & $-0.136(1.072)$ & $0.183(0.190)$ & 19.59 (16.52) \\
\hline Risk aversion & $4.144 * *(1.941)$ & $59.12^{* * *}(12.03)$ & $5.869 * *(2.816)$ & $1165^{* * *}(199.7)$ \\
\hline Age & $0.012(0.014)$ & $-0.058(0.141)$ & $0.011(0.024)$ & $2.456(1.766)$ \\
\hline Gender & $-0.536(0.423)$ & $-0.995(3.686)$ & $-0.019(0.470)$ & $-9.869(44.46)$ \\
\hline Education & $0.178^{* * *}(0.051)$ & $0.582(0.523)$ & $0.125(0.154)$ & $49.56^{* * *}(8.379)$ \\
\hline Household size & $-0.174(0.126)$ & $2.131 *(1.157)$ & $-0.046(0.141)$ & $-0.677(12.39)$ \\
\hline Farm size & $0.083^{* * *}(0.032)$ & $-0.624^{* *}(0.330)$ & $-0.006(0.028)$ & $-2.086(1.755)$ \\
\hline Asset & $0.078(0.257)$ & $8.273^{* * *}(2.532)$ & $0.629(0.542)$ & $13.06(35.43)$ \\
\hline Soil fertility & $-0.901^{* * *}(0.158)$ & $-10.478^{* * *}(1.752)$ & $-0.012(0.282)$ & $-225.1^{* * *}(27.43)$ \\
\hline Tenure security & $0.243(0.268)$ & $4.661(4.494)$ & $1.654^{* * *}(0.443)$ & $41.82(45.49)$ \\
\hline Membership & $0.127(0.294)$ & $7.860^{* * *}(2.570)$ & $-0.332(0.607)$ & $163.4^{* * *}(40.29)$ \\
\hline Training & $0.523 * *(0.258)$ & $7.025^{* * *}(2.565)$ & $0.421(0.447)$ & $95.71^{* * *}(33.84)$ \\
\hline Distance to farm & $0.045(0.147)$ & 0.685 (1.422) & $-0.269(0.227)$ & $20.14(19.34)$ \\
\hline Wald $\chi^{2}$ & \multirow{2}{*}{\multicolumn{2}{|c|}{$78.52 * * *(0.000)$}} & \multicolumn{2}{|c|}{$39.91^{* * *}(0.002)$} \\
\hline Log likelihood & & & \multicolumn{2}{|c|}{-885.2} \\
\hline
\end{tabular}

Notes: Standard errors are reported in parentheses. ${ }^{*}, * *$, and ${ }^{* * *}$ indicate statistical significance at $10 \%, 5 \%$, and $1 \%$ levels, respectively. Source: Authors' survey.

For both rice and banana farmers, perceived yield-increasing, quality-improving effects, and cost increases significantly affected the farmers' organic fertilizer adoption decision (the first hurdle). However, the perceived quality-improving effect was not associated with the investment level among rice farmers (the second hurdle). It was therefore implied that, once a rice farmer decided to adopt organic fertilizer, the investment level was independent of the quality-improving effect, but rather the yield-cost tradeoff. Also, the perceived cost increase had no significant impact on the organic fertilizer investment level for banana farmers, which was only affected by yield and quality effects. This makes sense as banana crop need a larger amount of organic fertilizer and small fluctuations of its price may not prevent it from being cost-beneficial. Moreover, the earlier-found impact of the perceived soil-improving effect was confirmed in the investment model for banana farmers, though it did not affect the adoption decision. Lastly, environmental friendliness was again found to be independent of organic fertilizer adoption and investment.

Risk attitude was associated with both organic fertilizer adoption and investment level, which were significant for both crops. Risk-averse farmers were not only more likely to adopt organic fertilizer, but also tended to invest more. The result is consistent with Monjardino et al. [36] and Bezabih and Sarr [52] with respect to farmer's risk-averse decisions in Australia and Ethiopia. These findings are generally consistent with our main results, lending credence to the latter. Moreover, since the double-hurdle model differentiated adoption decision making and investment level, Table 4 provides additional insights to farmers' organic fertilizer use and may potentially assist policy decisions that target farmers' specific decision stages in this regard.

Certain discrepancies were also observed among the coefficient estimates of other covariates. For instance, the impact of farm size on rice farmers' organic fertilizer use was positive and significant in the Tobit model, yet such impact bore opposite signs in different hurdles of decision making. In context, this means that larger farmers tended to adopt organic fertilizer but not necessarily invest more. Also, tenure security was not significant in the rice model. This was possible as many rice farmers believed their land tenure (about $70 \%$ of total sample reported in Table 1) was secure, and so the variation was small. These discrepancies again provided additional information to our understanding of farmers' organic fertilizer use. Since we were primarily interested in perceptions and risk attitude, the above estimates generally confirmed the impacts assessed in our earlier procedure, and concerns over the robustness of our main results should be minimized. 


\section{Discussion}

The above results consistently suggest that the perceptions and risk attitude played important roles in organic fertilizer investment. Among multiple perceived traits considered in the analysis, farmers' investment decisions were largely affected by the profit function arguments, namely the yield-increasing and quality-improving effects associated with organic fertilizer use, as well as a perceived cost increase. Crop-specific analysis further suggests that the soil improving effect of organic fertilizer was also important in banana production. However, environmental friendliness appeared to be unattractive to farmers, who may usually be myopic in developing countries and may need community-level coordination in providing environmental goods that benefit themselves in the long run $[5,18]$.

The confirmed roles of perceptions and risk attitude in organic fertilizer investment have directed policy implications regarding environmental and agricultural sustainability in China. First, farmers' awareness and knowledge of the benefits of organic fertilizer can be potential targets of extension efforts that aim to promote organic fertilizer adoption and investment. For many years in the past, the highest level of chemical fertilizer use per hectare in China only got an intermediate amount of average crop yields relative to the rest of the world [2]. Actually the application of organic or organic-chemical fertilizer compounds may reduce the use and improve the efficiency of chemical fertilizers and improve the long-term productivity [49]. Therefore, knowledge training and demonstration about organic fertilizer use through the direct engagement of farmers in the field could be an effective approach to increasing awareness regarding the advantages of organic fertilizer use $[11,18]$. Second, the cost factor cannot be overemphasized, which may deserve consideration of support in the short term and should be reduced through supply-chain efficiency improvement in the long term. That may imply interventions such as a subsidy for organic fertilizer processing technology, efficient and low-cost organic fertilizer research and development, and promotion and training to stimulate farm households to apply organic fertilizer [15]. Third, the risk-mitigating effect of organic fertilizer, if increasingly understood, may further incentivize the switch towards its use. In developing policies to stimulate the switch from chemical fertilizer to organic fertilizer, it is important to consider the relationship between various types of agricultural risks, the risk preferences of farmers, and farmers' input decisions [39]. Fourth, the so found impact was heterogeneous between rice and banana farmers, and intervention designs may need to be crop-specific. Given these notions, possible considerations include enhancement in field demonstrations of organic fertilizer application, as well as cost reduction through a variety of mechanisms, such as market regulation and provision of financial incentives to supply-side technological innovation, should consider specific crop features.

Additional insights were also provided by covariate impact estimates. To be specific, promoting the development of farmers' cooperatives and strengthening land tenure security can have positive impacts on investment in organic fertilizer. Improving tenancy contracts through longer tenure durations [21] and strengthening the cooperatives to provide more input service of organic fertilizers can be considered $[13,19]$.

While our findings do not speak directly to the merits of these policies, they are worth careful consideration from central to local governments that aim to reduce chemical fertilizer use to realize sustainable agricultural development. The comparative analysis of rice and banana crops as examples of staple and horticultural crops, respectively, further confirms the need to consider crop features in promoting organic fertilizer investment. Although the results may not be universally consistent in the developing world, they could be potentially informative to areas with similar agro-ecological environments or areas at similar developmental stages where farmers' organic fertilizer perceptions and risk attitude are comparable.

\section{Conclusions}

Using a recent survey of rice and banana farmers from Guangxi province, China, we assessed the impacts of perceptions and risk preference on farmers' organic fertilizer investment. Through the 
estimation of a Tobit model, it was found that several perceived traits of organic fertilizer, including yield-increasing, quality-improving, and cost-increasing effects, as well as risk aversion, elicited from a lottery choice experiment, significantly affected farmers' investment behavior. These results were further compared and contrasted with estimates from an OLS regression that modeled chemical fertilizer investment, where most of these factors had opposite impacts on the use of the latter. Our main findings regarding organic fertilizer use were further validated in a robustness exercise where a double-hurdle model that differentiated adoption decision and investment level was estimated.

Our study adds to the literature by identifying the roles of farmers' perceptions and risk attitude in a typical agricultural region in China. Also, we confirmed the impact heterogeneity between rice and banana crops and suggested the need to design policy tools on a crop-specific basis to improve their cost-effectiveness. The remaining limitations, such as the cross-sectional nature of data and the specific geographical focus, jointly call for further research to help establish the external validity of the findings. Potential policies as discussed above may need further evaluation in context before implementation to maximize their cost-effectiveness.

Author Contributions: For this paper, X.C. and D.Z. conceived and designed the research framework; X.C. and X.F. were in charge of the survey and analyzed the data; X.C., D.Z., and Y.X. contributed the analysis tools of this paper; X.C. and D.Z. wrote the paper; all authors revised the paper several times.

Funding: This research was funded by National Natural Sciences Foundation of China (Grant No. 71663008), the Ministry of Education of Humanities and Social Science Project (Grant No. 16XJC790002), the Natural Sciences Foundation of Guangxi Province (Grant No. 2015GXNSFBA139092), and China Scholarship Council (CSC No. 201706665005).

Conflicts of Interest: The authors declare no conflict of interest.

\section{Appendix A Risk Preference Estimation Using Lottery-Choice Experiment}

Table A1. Risk preference estimation design: lottery-choice decision.

\begin{tabular}{ccc}
\hline Decision & \multicolumn{1}{c}{ Option A } & Option B \\
\hline 1 & $10 \%$ of 10,000 Yuan, $90 \%$ of 8000 Yuan & $10 \%$ of 19,000 Yuan, $90 \%$ of 1000 Yuan \\
2 & $20 \%$ of 10,000 Yuan, $80 \%$ of 8000 Yuan & $20 \%$ of 19,000 Yuan, $80 \%$ of 1000 Yuan \\
3 & $30 \%$ of 10,000 Yuan, $70 \%$ of 8000 Yuan & $30 \%$ of 19,000 Yuan, $70 \%$ of 1000 Yuan \\
4 & $40 \%$ of 10,000 Yuan, $60 \%$ of 8000 Yuan & $40 \%$ of 19,000 Yuan, $60 \%$ of 1000 Yuan \\
5 & $50 \%$ of 10,000 Yuan, $50 \%$ of 8000 Yuan & $50 \%$ of 19,000 Yuan, $50 \%$ of 1000 Yuan \\
6 & $60 \%$ of 10,000 Yuan, $40 \%$ of 8000 Yuan & $60 \%$ of 19,000 Yuan, $40 \%$ of 1000 Yuan \\
7 & $70 \%$ of 10,000 Yuan, 30\% of 8000 Yuan & $70 \%$ of 19,000 Yuan, 30\% of 1000 Yuan \\
8 & $80 \%$ of 10,000 Yuan, 20\% of 8000 Yuan & $80 \%$ of 19,000 Yuan, $20 \%$ of 1000 Yuan \\
9 & $90 \%$ of 10,000 Yuan, 10\% of 8000 Yuan & $90 \%$ of 19,000 Yuan, $10 \%$ of 1000 Yuan \\
10 & $100 \%$ of 10,000 Yuan, $0 \%$ of 8000 Yuan & $100 \%$ of 19,000 Yuan, $\%$ of 1000 Yuan \\
\hline
\end{tabular}

Notes: The experiment using Chinese Yuan 10,000 (\$1500) as a payoff from actual farming activity. In the first decision, the probability of the high payoff for both options is $10 \%$, so only an extreme risk seeker would choose Option B. A risk neutral farmer would choose option A for the first four decisions because the expected value of A exceeds the expected value B. As the farmer's decision moves down, the possibility of winning the higher payoff increases in both options. Finally, assuming farmers exhibit constant absolute risk aversion $\operatorname{ar}(w)=-U^{\prime \prime}(W) / U \prime(W), U(x)=-\exp (-\operatorname{ar} \times x)$, where ar is the coefficient of absolute risk aversion. Farmer's risk aversion is distribution reported in Table A2. Source: Authors' survey. 
Table A2. Farmers' risk aversion distribution based on lottery choices experiment.

\begin{tabular}{|c|c|c|c|c|c|c|}
\hline \multirow{2}{*}{ Choices Number } & \multirow{2}{*}{$\begin{array}{c}\text { Range of Absolute } \\
\text { Risk Aversion }\end{array}$} & \multirow{2}{*}{ Risk Aversion Class } & \multicolumn{2}{|c|}{ Rice } & \multicolumn{2}{|c|}{ Banana } \\
\hline & & & Frequency & $\%$ & Frequency & $\%$ \\
\hline 1 & $a r<-0.11$ & Highly risk loving & 2 & $0.55 \%$ & 6 & $2.50 \%$ \\
\hline 2 & $-0.11<$ ar $<-0.06$ & Very risk loving & 9 & $2.47 \%$ & 16 & $6.67 \%$ \\
\hline 3 & $-0.06<a r<-0.02$ & Risk loving & 23 & $6.30 \%$ & 25 & $10.42 \%$ \\
\hline 4 & $-0.02<a r<0.03$ & Risk neutral & 29 & $7.95 \%$ & 28 & $11.67 \%$ \\
\hline 5 & $0.03<$ ar $<0.07$ & Slightly risk averse & 62 & $16.99 \%$ & 47 & $19.58 \%$ \\
\hline 6 & $0.07<$ ar $<0.11$ & Risk averse & 95 & $26.03 \%$ & 56 & $23.33 \%$ \\
\hline 7 & $0.11<$ ar $<0.17$ & Very risk averse & 81 & $22.19 \%$ & 44 & $18.33 \%$ \\
\hline 8 & $0.17<a r<0.25$ & Highly risk averse & 51 & $13.97 \%$ & 14 & $5.83 \%$ \\
\hline \multirow[t]{2}{*}{$9-10$} & $0.25<a r$ & Stay in bed & 13 & $3.56 \%$ & 4 & $1.67 \%$ \\
\hline & Number of observati & & 365 & $100 \%$ & 240 & $100 \%$ \\
\hline
\end{tabular}

Notes: Using the assuming utility function and the formula of absolute risk aversion coefficient, the choices can be used to determine a range on a farmer's coefficient of absolute risk aversion, and the measure of the midpoint of the minimum and maximum ar was used in our analysis. We defined the classification of farmer's risk aversion following Binswanger and Sillers [47], Holt and Laury [34], and Yusuf [35]. For example, a farmer that chose option A for the first six decision tasks then chose option B for the last four decisions had an ar between 0.07 and 0.11 and the farmer's ar would be set at a value of 0.09 for the analysis. Source: Authors' survey.

\section{References}

1. Zhang, X.; Davidson, E.A.; Mauzerall, D.L.; Searchinger, T.D.; Dumas, P.; Shen, Y. Managing nitrogen for sustainable development. Nature 2015, 528, 51. [CrossRef] [PubMed]

2. Wu, Y.; Xi, X.; Tang, X.; Luo, D.; Gu, B.; Lam, S.K.; Vitousek, P.M.; Chen, D. Policy distortions, farm size, and the overuse of agricultural chemicals in China. Proc. Natl. Acad. Sci. USA 2018, 7010-7015. [CrossRef] [PubMed]

3. Yang, Q.; Liu, J.; Zhang, Y. Decoupling agricultural nonpoint source pollution from crop production: A case study of Heilongjiang land reclamation area, China. Sustainability 2017, 9, 1024. [CrossRef]

4. Xie, H. Towards sustainable land use in China: A collection of empirical studies. Sustainability 2017, 9, 2129. [CrossRef]

5. Dong, G.; Mao, X.; Zhou, J.; Zeng, A. Carbon footprint accounting and dynamics and the driving forces of agricultural production in Zhejiang Province, China. Ecol. Econ. 2013, 91, 38-47. [CrossRef]

6. Miao, Y.; Stewart, B.A.; Zhang, F. Long-term experiments for sustainable nutrient management in China. A review. Agron. Sustain. Dev. 2011, 31,397-414. [CrossRef]

7. State-Statistical-Bureau. China Statistical Yearbook 2016; Statistical Press of China: Beijing, China, 2016.

8. Food and Agriculture Organization (FAO). World Fertilizer Trends and Outlook to 2018; Annual Report 14; Food and Agriculture Organization of the United Nations (FAO): Rome, Italy, 2015; ISBN 978-92-5-108692-6.

9. Zhang, D.; Wang, H.; Pan, J.; Luo, J.; Liu, J.; Gu, B.; Liu, S.; Zhai, L.; Lindsey, S.; Zhang, Y.; et al. Nitrogen application rates need to be reduced for half of the rice paddy fields in China. Agric. Ecosyst. Environ. 2018, 265, 8-14. [CrossRef]

10. Li, X.; Gong, Q. Trend and direction of China's development of regulatory policies preventing over-fertilization in farming. Res. Agric. Mod. 2016, 37, 877-884. (In Chinese) [CrossRef]

11. Li, Q.; Yang, W.; Li, K. Role of social learning in the diffusion of environmentally-friendly agricultural technology in China. Sustainability 2018, 10, 1527. [CrossRef]

12. Yang, Z.C.; Zhao, N.; Huang, F.; Lv, Y.Z. Long-term effects of different organic and inorganic fertilizer treatments on soil organic carbon sequestration and crop yields on the north China plain. Soil Tillage Res. 2015, 146, 47-52. [CrossRef]

13. Ma, W.; Abdulai, A.; Goetz, R. Agricultural cooperatives and investment in organic soil amendments and chemical fertilizer in China. Am. J. Agric. Econ. 2017. [CrossRef]

14. Wang, H.; Hu, R.; Chen, X.; Zhong, X.; Zheng, Z.; Huang, N.; Xue, C. Reduction in nitrogen fertilizer use results in increased rice yields and improved environmental protection. Int. J. Agric. Sustain. 2017, 15, 681-692. [CrossRef]

15. Xu, H.; Huang, X.; Zhong, T.; Chen, Z.; Yu, J. Chinese land policies and farmers' adoption of organic fertilizer for saline soils. Land Use Policy 2014, 38, 541-549. [CrossRef] 
16. Holden, S.T.; Deininger, K.; Ghebru, H. Impacts of low-cost land certification on investment and productivity. Am. J. Agric. Econ. 2009, 91, 359-373. [CrossRef]

17. Quynh, H.; Kazuto, S. “Organic fertilizers” in Vietnam's markets: Nutrient composition and efficacy of their application. Sustainability 2018, 10, 2437. [CrossRef]

18. Huang, J.; Huang, Z.; Jia, X.; Hu, R.; Xiang, C. Long-term reduction of nitrogen fertilizer use through knowledge training in rice production in China. Agric. Syst. 2015, 135, 105-111. [CrossRef]

19. Wang, Y.; Zhu, Y.; Zhang, S.; Wang, Y. What could promote farmers to replace chemical fertilizers with organic fertilizers? J. Clean. Prod. 2018, 199, 882-890. [CrossRef]

20. Ministry-Of-Agriculture. National Agricultural Sustainable Development Plan of China (2015-2030); Ministry-Of-Agriculture: Beijing, China, 2015.

21. Rakhshanda, K.; Awudu, A. Off-farm work, land tenancy contracts and investment in soil conservation measures in rural Pakistan. Aust. J. Agric. Resour. Econ. 2016, 60, 307-325. [CrossRef]

22. Yusuf, M.; Mustafa, F.; Salleh, K. Farmer perception of soil erosion and investment in soil conservation measures: Emerging evidence from northern taraba state, Nigeria. Soil Use Manag. 2017, 33, 163-173. [CrossRef]

23. Hasler, K.; Olfs, H.-W.; Omta, O.; Bröring, S. Drivers for the adoption of eco-innovations in the German fertilizer supply chain. Sustainability 2016, 8, 682. [CrossRef]

24. Bai, Y.; Kung, J.; Zhao, Y. How much expropriation hazard is too much? The effect of land reallocation on organic fertilizer usage in rural China. Land Econ. 2014, 90, 434-457. [CrossRef]

25. Jacoby, H.G.; Li, G.; Rozelle, S. Hazards of expropriation: Tenure insecurity and investment in rural China. Am. Econ. Rev. 2002, 92, 1420-1447. [CrossRef]

26. Abdulai, A.; Owusu, V.; Goetz, R. Land tenure differences and investment in land improvement measures: Theoretical and empirical analyses. J. Dev. Econ. 2011, 96, 66-78. [CrossRef]

27. Li, G.; Rozelle, S.; Brandt, L. Tenure, land rights, and farmer investment incentives in China. Agric. Econ. 1998, 19, 63-71. [CrossRef]

28. Arcand, J.-L.; Ai, C.; Éthier, F. Moral hazard and marshallian inefficiency: Evidence from Tunisia. J. Dev. Econ. 2007, 83, 411-445. [CrossRef]

29. Gao, L.; Huang, J.; Rozelle, S. Rental markets for cultivated land and agricultural investments in China. Agric. Econ. 2012, 43, 391-403. [CrossRef]

30. Case, S.; Oelofse, M.; Hou, Y.; Oenema, O.; Jensen, L.S. Farmer perceptions and use of organic waste products as fertilisers-A survey study of potential benefits and barriers. Agric. Syst. 2017, 151, 84-95. [CrossRef]

31. Adimassu, Z.; Kessler, A.; Yirga, C.; Stroosnijder, L. Farmers' perceptions of land degradation and their investments in land management: A case study in the central rift valley of Ethiopia. Environ. Manag. 2013, 51,989-998. [CrossRef] [PubMed]

32. Hou, Y.; Velthof, G.L.; Case, S.D.C.; Oelofse, M.; Grignani, C.; Balsari, P.; Zavattaro, L.; Gioelli, F.; Bernal, M.P.; Fangueiro, D.; et al. Stakeholder perceptions of manure treatment technologies in Denmark, Italy, The Netherlands and Spain. J. Clean. Prod. 2018, 172, 1620-1630. [CrossRef]

33. Binswanger, H.P. Attitudes toward risk: Experimental measurement in rural India. Am. J. Agric. Econ. 1980, 62, 395-407. [CrossRef]

34. Holt, C.A.; Laury, S.K. Risk aversion and incentive effects. Am. Econ. Rev. 2002, 92, 1644-1655. [CrossRef]

35. Yesuf, M.; Bluffstone, R.A. Poverty, risk aversion, and path dependence in low-income countries: Experimental evidence from Ethiopia. Am. J. Agric. Econ. 2009, 91, 1022-1037. [CrossRef]

36. Monjardino, M.; McBeath, T.; Ouzman, J.; Llewellyn, R.; Jones, B. Farmer risk-aversion limits closure of yield and profit gaps: A study of nitrogen management in the southern Australian wheatbelt. Agric. Syst. 2015, 137, 108-118. [CrossRef]

37. Wossen, T.; Berger, T.; Di Falco, S. Social capital, risk preference and adoption of improved farm land management practices in Ethiopia. Agric. Econ. 2015, 46, 81-97. [CrossRef]

38. Nielsen, T.; Keil, A.; Zeller, M. Assessing farmers' risk preferences and their determinants in a marginal upland area of Vietnam: A comparison of multiple elicitation techniques. Agric. Econ. 2013, 44, 255-273. [CrossRef]

39. Isik, M. Resource management under production and output price uncertainty: Implications for environmental policy. Am. J. Agric. Econ. 2002, 84, 557-571. [CrossRef] 
40. Simtowe, F.; Mduma, J.; Phiri, A.; Thomas, A.; Zeller, M. Can risk-aversion towards fertilizer explain part of the non-adoption puzzle for hybrid maize? Empirical evidence from Malawi. J. Appl. Sci. 2006, 6, 1490-1498.

41. Ramaswami, B. Production risk and optimal input decisions. Am. J. Agric. Econ. 1992, 74, 860-869. [CrossRef]

42. Groom, B.; Koundouri, P.; Nauges, C.; Thomas, A. The story of the moment: Risk averse cypriot farmers respond to drought management. Appl. Econ. 2008, 40, 315-326. [CrossRef]

43. Lamb, R.L. Fertilizer use, risk, and off-farm labor markets in the semi-arid tropics of India. Am. J. Agric. Econ. 2003, 85, 359-371. [CrossRef]

44. Isik, M.; Khanna, M. Stochastic technology, risk preferences, and adoption of site-specific technologies. Am. J. Agric. Econ. 2003, 85, 305-317. [CrossRef]

45. Bureau-Of-Guangxi-Statistical. Guangxi Statistical Yearbook; Statistical Press of China: Beijing, China, 2017.

46. Cragg, J.G. Some statistical models for limited dependent variables with application to the demand for durable goods. Econom. J. Econom. Soc. 1971, 39, 829-844. [CrossRef]

47. Binswanger, H.P.; Sillers, D.A. Risk aversion and credit constraints in farmers' decision-making: A reinterpretation. J. Dev. Stud. 1983, 20, 5-21. [CrossRef]

48. Lusk, J.L.; Coble, K.H. Risk perceptions, risk preference, and acceptance of risky food. Am. J. Agric. Econ. 2005, 87, 393-405. [CrossRef]

49. Zhao, J.; Ni, T.; Li, J.; Lu, Q.; Fang, Z.; Huang, Q.; Zhang, R.; Li, R.; Shen, B.; Shen, Q. Effects of organic-inorganic compound fertilizer with reduced chemical fertilizer application on crop yields, soil biological activity and bacterial community structure in a rice-wheat cropping system. Appl. Soil Ecol. 2016, 99, 1-12. [CrossRef]

50. Evanylo, G.; Sherony, C.; Spargo, J.; Starner, D.; Brosius, M.; Haering, K. Soil and water environmental effects of fertilizer-, manure-, and compost-based fertility practices in an organic vegetable cropping system. Agric. Ecosyst. Environ. 2008, 127, 50-58. [CrossRef]

51. Lahav, E. Effect of different amounts of potassium on growth of the banana. Trop. Agric. 1972, 49, 321-335.

52. Bezabih, M.; Sarr, M. Risk preferences and environmental uncertainty: Implications for crop diversification decisions in Ethiopia. Environ. Resour. Econ. 2012, 53, 483-505. [CrossRef]

(C) 2018 by the authors. Licensee MDPI, Basel, Switzerland. This article is an open access article distributed under the terms and conditions of the Creative Commons Attribution (CC BY) license (http:/ / creativecommons.org/licenses/by/4.0/). 